\title{
Apoptotic mechanisms of nickel(II) complex with N1-acetylacetone-N4- 4-methoxy-salicylidene-S-allyl-thiosemicarbazone on HL60 leukemia cells
}

\author{
Büşra Kaya, Belkis Atasever-Arslan, Zeynep Kalkan, Hazal Gür, Bahri Ülküseven \\ ${ }^{1}$ Department of Chemistry, Faculty of Engineering, İstanbul University, Istanbul, Turkey \\ ${ }^{2}$ Department of Molecular Biology and Genetics, Faculty of Engineering and Natural Sciences, Üsküdar University, Istanbul, \\ Turkey \\ ${ }^{3}$ Neuroscience Program, Health Sciences Institute, Üsküdar University, Istanbul, Turkey \\ ${ }^{4}$ Department of Bioengineering, Faculty of Engineering and Natural Sciences, Üsküdar University, Istanbul, Turkey
}

\begin{abstract}
Thiosemicarbozone complexes that have a broad spectrum of biological activity are formed as a result of condensation reaction between thiosemicarbazide $\left[\mathrm{H}_{2} \mathrm{~N}(\mathrm{C}=\mathrm{S})-\mathrm{NH}-\mathrm{NH}_{2}\right]$ and carbonyl-containing compounds. A new nickel(II) complex with N1-acetylacetone-N4-4-methoxysalicylidene-S-allyl-thiosemicarbazone ligand was synthesized and characterized. We studied the antileukemic activity of the $\mathrm{Ni}(\mathrm{II})$ thiosemicarbazone compound and assessed their potential for drug development. Specifically, the effects of this $\mathrm{Ni}(\mathrm{II})$ thiosemicarbazone compound on intracellular signal nodes and apoptotic pathways were investigated. According to our results, the $\mathrm{Ni}(\mathrm{II})$ thiosemicarbazone compound has apoptotic activity against HL60 cells. Moreover, while Ni(II) thiosemicarbazone compound significantly increased levels of $\mathrm{p} 53$ and cleaved caspase-3 proteins, it decreased level of Phospho-Akt1 protein in HL60 cells. The Ni(II) thiosemicarbazone compound could induce HL60 cell apoptosis through inhibiting of PI3K/Akt pathway. These results showed that $\mathrm{Ni}(\mathrm{II})$ thiosemicarbozone compound might be an antileukemic agent.
\end{abstract}

Key words: Thiosemicarbazone - Apoptosis - HL60 human promyelocytic leukemia cell - Signal transduction

\section{Introduction}

Thiosemicarbozone complexes that have a broad spectrum of biological activity are formed as a result of condensation reaction between thiosemicarbazide $\left[\mathrm{H}_{2} \mathrm{~N}(\mathrm{C}=\mathrm{S})-\mathrm{NH}-\mathrm{NH}_{2}\right]$ and carbonyl-containing compounds. Thiosemicarbozones are polydentate ligands and their aromatic derivatives have chelating ability with various metals. Metal complexes of thiosemicarbazones is one of the popular research subjects because of their wide range pharmacological activity that provides diverse variety of compounds and metal ions with different biological activities (Casas et al. 2000; Tarasconi et al. 2000; Beraldo and Gambino 2004; Yanardag et al. 2009;

Correspondence to: Belkis Atasever-Arslan, Department of Molecular Biology and Genetics, Faculty of Engineering and Natural Sciences, Uskudar University, Istanbul, Turkey

E-mail: belkisatasever.arslan@uskudar.edu.tr
Kesel 2011). Some of activities have antitumor (Afrasiabi et al. 2004; Vrdoljak et al. 2010), antimicrobial (De Logu et al. 2005; Rodriguez-Arguelles et al. 2005; Mendes et al. 2009), antiviral (Varadinova et al. 2001; Genova et al. 2004), and cytotoxic (Bal Demirci et al. 2007; Atasever et al. 2010) effects.

In various studies, it was found that metal complexes of some thiosemicarbozone compounds inhibit DNA synthesis and induce apoptosis. Especially, copper, palladium and platinum complexes of thiosemicarbazones are the most preferred compounds for drug potential studies (Otero et al. 2006; Matesanz and Souza 2007; Vieites et al. 2009; Raja et al. 2011). Furthermore, some significant findings regarding biological activities of vanadium (Noblia et al. 2005), manganese (Oliveira et al. 2014), iron and nickel (Bal Demirci et al. 2007; Atasever et al. 2010) chelates based on thiosemicarbazone have been shown.

Unfortunately, drug resistance still remains a major problem leukemias. Therefore developing new agents against 
leukemic cells is needed. Structures and biological activity make thiosemicarbazones strong therapeutics candidates.

In our previous studies, we demonstrated antileukemic activity of the iron (III) complexes of S-methylthiosemicarbazones with ONNO type. These previous results imply that their selective anticancer effects on various leukemic cells depends on not only metal ion in thiosemicarbazone complexes but also substituents and their location on aromatic rings. In this study, to analyse importance aromatic ring and $\mathrm{OCH}_{3}$ group, we investigated effects of the new synthesized N1-acetylacetone-N4-4-methoxy-salicylideneS-allyl-thiosemicarbazone chelating with nickel(II) against HL60 human promyelocytic leukemia cells (Figure 1). Specifically we studied its effects on intracellular signal nodes and apoptotic pathways in HL60 cells.

\section{Materials and Methods}

\section{Synthesis of the compounds}

Firstly, 2,4-pentanedione S-allyl-thiosemicarbazone was obtained as described in the literature (Yamazaki 1975). The cream colored compound melts at $144^{\circ} \mathrm{C}$. Yield: $65 \%$. Anal. Calc. for $\mathrm{C}_{9} \mathrm{H}_{15} \mathrm{~N}_{3} \mathrm{OS}$ (213.29): C, 50.68; H, 7.09; N, 19.70; S, 15.03. Found: C, 50.65; H, 7.10; N, 19.71; S, $15.00 \%$. UV-Vis: 208 (5.57), 217 (5.58), 226 (5.58), 392 (3.71). IR: $v_{\mathrm{as}}\left(\mathrm{NH}_{2}\right)$ $3188, v_{\mathrm{s}}\left(\mathrm{NH}_{2}\right) 3089, \delta(\mathrm{NH}), v\left(\mathrm{C}=\mathrm{N}^{1}\right), v\left(\mathrm{C}=\mathrm{N}^{2}\right) 1608-1555$, $v(\mathrm{C}-\mathrm{S}) 725 .{ }^{1} \mathrm{H}$ NMR: 9.43, 8.83 (cis/trans ratio: $2 / 1, \mathrm{~s}, 2 \mathrm{H}$, $\mathrm{NH}_{2}$ ), 7.77, 7.56 (cis/trans ratio: $\left.2 / 1, \mathrm{~s}, 1 \mathrm{H}, \mathrm{OH}\right), 5.86(\mathrm{~m}, 1 \mathrm{H}$, $\left.C^{2} H\right), 5.36\left(\mathrm{~d}, \mathrm{~J}=16.94,2 \mathrm{H},=\mathrm{C}^{3} \mathrm{HH}_{a}\right), 5.25(\mathrm{~d}, \mathrm{~J}=9.76,2 \mathrm{H}$, $\left.=\mathrm{C}^{3} \mathrm{HH}_{b}\right) 3.95\left(\mathrm{~s}, 2 \mathrm{H}, \mathrm{C}-\mathrm{CH}_{2}\right), 3.87(\mathrm{dd}, \mathrm{J}=5.85, \mathrm{~J}=6.95,2 \mathrm{H}$, $\left.\mathrm{S}-\mathrm{C}^{1} \mathrm{H}_{2}\right), 2.32\left(\mathrm{~s}, 3 \mathrm{H}, \mathrm{C}-\mathrm{CH}_{3}\right), 2.28\left(\mathrm{~s}, 3 \mathrm{H}, \mathrm{C}-\mathrm{CH}_{3}\right)$.

For synthesis of the nikel(II) complex, $\mathrm{NiCl}_{2} \cdot 6 \mathrm{H}_{2} \mathrm{O}(0.24$ $\mathrm{g}, 1 \mathrm{mmol})$ was dissolved in methanol $(5 \mathrm{ml})$ and then 1.5 $\mathrm{ml}$ of orthoformic ester was added to the solution. After standing for $24 \mathrm{~h}$ at room temperature, a solution of the thiosemicarbazone $(0.21 \mathrm{~g}, 1 \mathrm{mmol})$ and 2-hydroxy-4-meth-

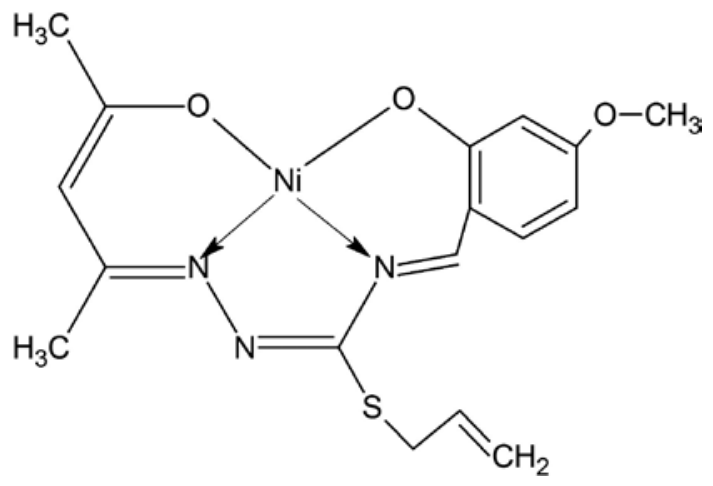

Figure 1. The $\mathrm{N}_{2} \mathrm{O}_{2}$ nickel complex. oxybenzaldehyde $(0.152 \mathrm{~g}, 1 \mathrm{mmol})$ in $5 \mathrm{ml}$ methanol was added dropwise to the metal salt solution. After the additon of triethylamine $(0.1 \mathrm{mmol})$, the mixture was left to stand at room temperature overnight. The red crystals was filtered, and recrystalized from ethanol-dichloromethane. Yield: $45 \%$. m.p. $189.5^{\circ} \mathrm{C}$. Anal. Calc. for $\mathrm{C}_{17} \mathrm{H}_{19} \mathrm{~N}_{3} \mathrm{NiO}_{3} \mathrm{~S}(404.109$ g): C, 50.53; H, 4.47; N, 10.40; S, 7.93. Found: C, 50.55; H, 4.50; N, 10.38; S, 7.90 \%. UV-Vis: 228 (5.64), 306 (4.91), 339 (4.64) 355 (4.66), 409 (4.73), 425 (4.75), 515 (3.42). IR: $v\left(\mathrm{C}=\mathrm{N}^{1}\right) 1612, v\left(\mathrm{C}=\mathrm{N}^{2}\right) 1583, v\left(\mathrm{~N}^{4}=\mathrm{C}\right) 1542, v(\mathrm{C}-\mathrm{O}) 1173$, 1135. ${ }^{1} \mathrm{H}$ NMR: 7.71(s, $\left.1 \mathrm{H}, \mathrm{N}^{4}=\mathrm{CH}\right), 7.15(\mathrm{~d}, J=9.27,1 \mathrm{H}, c)$, $6.54(\mathrm{~s}, 1 \mathrm{H}, a), 6.3(\mathrm{~d}, J=8.78,1 \mathrm{H}, b), 5.87\left(\mathrm{~m}, 1 \mathrm{H}, C^{2} H\right), 5.23$ $\left(\mathrm{d}, \mathrm{J}=17.08,2 \mathrm{H},=\mathrm{C}^{3} H H_{a}\right), 5.11\left(\mathrm{~d}, \mathrm{~J}=9.76,2 \mathrm{H},=\mathrm{C}^{3} H H_{b}\right)$, $5.16(\mathrm{~s}, 1 \mathrm{H},=\mathrm{CH}), 3.74\left(\mathrm{~d}, \mathrm{~J}=7.322 \mathrm{H}, \mathrm{S}-\mathrm{C}^{1} \mathrm{H}_{2}\right), 3.72(\mathrm{~s}, 3 \mathrm{H}$, $\left.\mathrm{O}-\mathrm{CH}_{3}\right), 2.25\left(\mathrm{~s}, 3 \mathrm{H}, \mathrm{C}-\mathrm{CH}_{3}\right), 2.05\left(\mathrm{~s}, 3 \mathrm{H}, \mathrm{C}-\mathrm{CH}_{3}\right)$.

\section{Mammalian cell culture}

Cytotoxic potential of $\mathrm{Ni}$ (II) thiosemicarbazone compound was assessed on HL60 cells. ECV304 (human umbilical vein endothelial cell line) was used as non-cancerous cellular control because ECV304 cell line presents many features of endothelial cells (Suda et al. 2001). The cell lines were purchased from ATCC.

RPMI medium for suspension cells (Panbiotech P0416100) and DMEM medium for adhesive cells (HyClone, 16777-133) were supplemented with $10 \%$ fetal bovine serum (HyClone, SH3007003HI), 1\% penicillin-streptomycin, 1\% L-Glutamine and $0.1 \%$, and MEM non-essential amino acids. Cell lines were incubated in a humidified atmosphere containing $5 \% \mathrm{CO}_{2}$ at $37^{\circ} \mathrm{C} .75 \mathrm{ml}$ polystyrene cell culture flasks and 96-well plates (Greiner) were used for cell culture and viability assays, respectively. Adhesive ECV304 cells, were detached by $0.5 \%$ Trypsin-EDTA solution (Sigma, T3924), washed once with 10\% FBS containing medium and twice with PBS and resuspended in DMEM at density of $1 \times 10^{5}$ cells $/ \mathrm{ml}$.

\section{Cytotoxicity assay}

The cytotoxic effect of $\mathrm{Ni}(\mathrm{II})$ thiosemicarbazone compound on HL60 human promyelocytic leukemia and ECV304 human endothelial cells were measured with MTT (3-(4,5-dimethylthiazol-2yl)2,5-diphenyl tetrazolium bromide) assay (Sigma, M-5655) as previously described Pirildar et al. (2010), Svobodova et al. (2012) and Atasever-Arslan et al. (2015). HL60 cells were resuspended at $1 \times 10^{6}$ cells $/ \mathrm{ml}$ in RPMI medium, ECV304 cells were resuspended at $1 \times 10^{6}$ cells $/ \mathrm{ml}$ in DMEM medium at $37^{\circ} \mathrm{C}$ in a humidified atmosphere containing $5 \% \mathrm{CO}_{2}$.

Stock solutions of the thiosemicarbazone were prepared in DMSO at a concentration of $10 \mathrm{mg} / \mathrm{ml}$. Serial dilutions of the stock solution were prepared in absolute methanol. 
$90 \mu \mathrm{l}$ of cell cultures were dispensed into 96-well roundbottom plates containing $10 \mu \mathrm{l}$ of $\mathrm{Ni}$ (II) thiosemicarbazone compound dilutions. Thus, the final concentrations of the compound were $124,25,12,2.5,0.25 \mu \mathrm{mol} / \mathrm{l}$. As a negative control, only $10 \mu \mathrm{l}$ of medium containing appropriately diluted methanol was used instead of $\mathrm{Ni}$ (II) thiosemicarbazone compound. After 48 hours of incubation, $10 \mu \mathrm{l}$ freshly prepared MTT solution $(5 \mathrm{mg} / \mathrm{ml})$ in phosphate buffer saline (PBS) was added to each well and the plates were incubated $3 \mathrm{~h}$ at $37^{\circ} \mathrm{C}$. Supernatants were removed from all wells and $100 \mathrm{ml}$ of sodium dodecyl sulfate (SDS, $\mathrm{pH}$ 5.5) containing isopropyl alcohol was added to the wells and the microplates were stored at room temperature in the dark, in order to dissolve the formazan crystals formed by reduction of MTT in living cells. Optical density (OD) of each well was measured at $570 \mathrm{~nm}$ test wavelength and at $655 \mathrm{~nm}$ reference wavelength on a Bio-Rad Benchmark Microplate Reader. Cytotoxicity index was calculated with the formula:

Cytotoxicity index $=1-$ [OD (treated wells) / OD (control wells)] $\times 100$ ). The cytotoxicity assay was repeated six times for each concentration of the compound.

According to MTT results, inhibitory concentration $\left(\mathrm{IC}_{50}\right.$ $=$ the concentration of the compound that inhibited $50 \%$ cells) was calculated from the data obtained using GraphPad Prism software.

\section{Flow cytometry analysis}

To determine the apoptotic and necrotic effects of the Ni(II) thiosemicarbazone compound on HL60 cells, we stained with Annexin V and Propodium iodide (PI) (Biolegend Inc.) and analyzed by flow cytometry (Atasever-Arslan et. al. 2016). Treated HL60 cells, were harvested from plates by centrifugation to remove the media and then washed with 1XFACS buffer (1X HBSS, $0.5 \%$ sodium azide and $0.5 \%$ BSA). Annexin V was diluted 1:100 with Annexin V binding buffer (0.1 M HEPES/NaOH (pH 7.4), $1.4 \mathrm{M} \mathrm{NaCl}, 0.05 \mathrm{M}$ $\mathrm{CaCl}_{2}$ ) and cells were resuspended in $500 \mu \mathrm{l}$ of this mixture. Samples were incubated for 20 minutes at room temperature in the dark, stored on ice and PI $(124 \mu \mathrm{mol} / \mathrm{l})$ was added immediately before analysis. Flow cytometric measurement of the samples was performed on a FACS Canto flow cytometer (BD Biosciences). Flow cytometry was repeated three times for each concentration of the compound. Data were analyzed with FlowJo 9.4.3 software (Treestar).

\section{DNA fragmentation assay}

After HL60 cells was incubated with the Ni(II) thiosemicarbazone compound $(124 \mu \mathrm{mol} / \mathrm{l})$ for 24 hours, cells were collected by centrifugation at 13,200 rpm for 20 seconds at room temperature. The supernatant was discarded and the pellet was transferred to a fresh microcentrifuge tube containing $600 \mu \mathrm{l}$ of ice-cold cell lysis buffer (10 mM Tris-Cl (ph8), 1 mM EDTA (ph8), \%0.1 (w/v) SDS). Three $\mu$ l of proteinase $\mathrm{K}$ solution $(20 \mathrm{mg} / \mathrm{ml})$ was added and incubated for 3 hours at $55^{\circ} \mathrm{C}$ followed by $1.5 \mu \mathrm{l}$ of RNAse $(4 \mathrm{mg} / \mathrm{ml})$ and an additional incubation for 15 min at $37^{\circ} \mathrm{C}$. Then, samples were cooled down to room temperature and $200 \mu \mathrm{l}$ potassium acetate solution was added and mixed. The samples were centrifuged $(13,200$ $\mathrm{rpm}$ ) for 3 minutes at $4^{\circ} \mathrm{C}$. Supernatants were transferred to fresh microcentrifuge tubes followed by the addition of $600 \mu \mathrm{l}$ isopropanol. The solution was mixed well and centrifuged at 13,200 $\mathrm{rpm}$ for $1 \mathrm{~min}$ at room temperature. The supernatant was removed and $600 \mu \mathrm{l}$ of $70 \%$ ethanol was added to the DNA pellet. The tube was inverted several times and centrifuged at 13,200 rpm for $1 \mathrm{~min}$ at room temperature. The supernatant was removed and the DNA pellet air dried for $15 \mathrm{~min}$ before being dissolved in $100 \mu \mathrm{l}$ TE buffer (Takaki et al. 2014). Isolated genomic DNA was resolved by $2 \%$ agarose gel electrophoresis for 40 minutes at $100 \mathrm{~V}$, stained in an Ethidium bromide solution (0.625 $\mathrm{mg} / \mathrm{ml}$ ) for $\mathrm{x}$ minutes and analyzed on a gel imaging system (Vilber Lourmat -02). The DNA fragmentation analyses were repeated twice.

\section{Spectrophotometric analysis of intracellular signal nodes and apoptotic signal pathways}

CST PathScan ${ }^{\circledast}$ Signaling Nodes and Apoptosis MultiTarget Sandwich ELISA kits (Cell Signaling Technologies, USA) were used to determine the effects of $\mathrm{Ni}$ (II) thiosemicarbazone compound on HL60 cells on signaling nodes and intracellular apoptotic signal pathways. Ni(II)treated HL60 cells were processed according to the manufacturer's instructions. Briefly, 1 million cells were lysed in lysis buffer, lysates aliquoted onto 96 well plates coated with antibodies and a sandwich ELISA was performed using specific antibodies and HRP labelled secondary antibodies, incubated with substrate. Assays were repeated six times. HRP enzymatic activity detected on Multiskan ${ }^{\mathrm{Tm}}$ GO Microplate Spectrophotometer (Spectrophotometric Determination) to quantify antigen concentration. Optical density (OD) of each well was measured at $450 \mathrm{~nm}$ test wavelength.

\section{Statistical analysis}

Statistical analysis was performed using Statistical Package for the Social Sciences (SPSS) software. Results were expressed as the mean \pm standard deviation (SD). Statistical differences were assessed by Student's unpaired $t$-test, with $p<0.05$ as a statistical significance cut-off. 


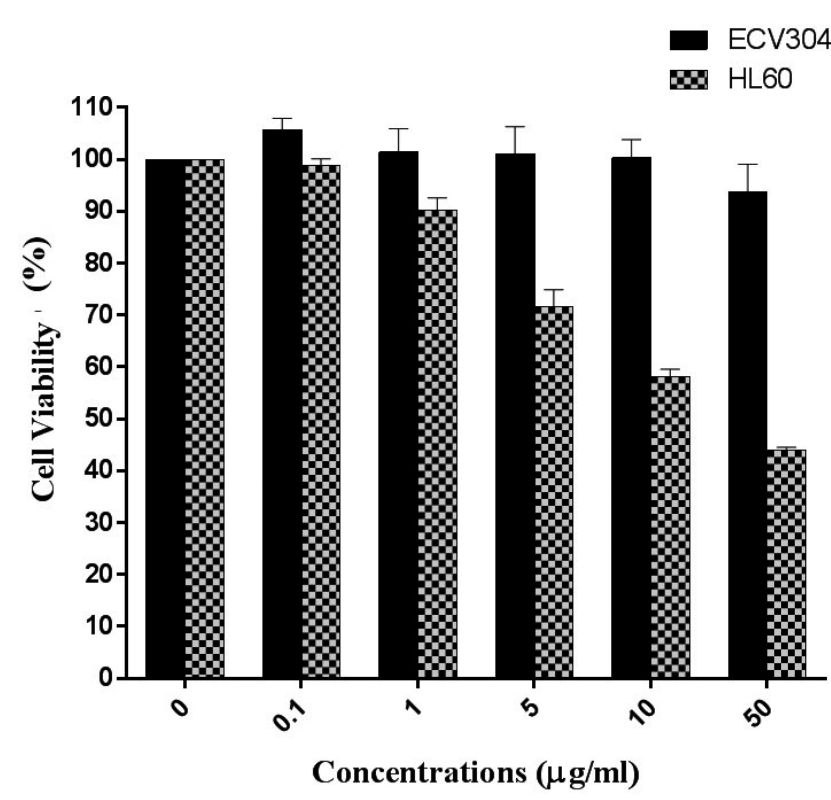

Figure 2. Cytotoxic effects of $\mathrm{Ni}(\mathrm{II})$ thiosemicarbazone compound against HL60 and ECV304 cell lines. The graphs show level of cell viability according to concentration of the compound. Cell viability of control group was accepted $100 \%$ and decrease in cell viability has been shown at $0.25,2.5,12,25$ and $124 \mu \mathrm{mol} / \mathrm{l}$, respectively.

\section{Results}

A nickel(II) complex with $\mathrm{N}_{2} \mathrm{O}_{2}$ chelating N1-acetylacetone-N4-4-methoxy-salicylidene-S-allyl-thiosemicarbazone ligand was synthesized and confirmed expected structure by elemental analysis, infrared and ${ }^{1} \mathrm{H}$ NMR spectra.
We investigated cytotoxic effect of $\mathrm{Ni}$ (II) thiosemicarbazone compound on HL60 human promyelocytic leukemia cells by using MTT cytotoxicity assay. As a control group, we used ECV304 human endothelial cells. HL60 and ECV304 cells were treated with $\mathrm{Ni}$ (II) thiosemicarbazone compound at different concentration $(124,25,12,2.5,0.25$ $\mu \mathrm{mol} / \mathrm{l})$ and cell viability was measured via MTT assay. Figure 2 shows the cytotoxic activity of $\mathrm{Ni}(\mathrm{II})$ thiosemicarbazone compound against HL60 human promyelocytic leukemia cells and ECV304 human endothelial cells. Ni(II) thiosemicarbazone compound did not show a significant cytotoxicity on ECV304 non-cancer control group cells. In addition, this compound caused proliferation of ECV304 cells. $\mathrm{Ni}(\mathrm{II})$ thiosemicarbazone compound showed cytotoxic activity above 55\% against HL60 cells in $124 \mu \mathrm{mol} / \mathrm{l}$ (Figure 2). Furthermore, it showed about $40 \%$ cytotoxicity on HL60 cells in $25 \mu \mathrm{mol} / \mathrm{l}$. According to the cytotoxicity results, $\mathrm{IC}_{50}$ values of HL60 and ECV304 cells are $58.8 \mu \mathrm{mol} / \mathrm{l}$ and $>124 \mu \mathrm{mol} / \mathrm{l}$, respectively. Apoptotic effect of the $\mathrm{Ni}(\mathrm{II})$ thiosemicarbazone compound on HL60 cells was analysed by using flow cytometry analysis. In order to discriminate apoptotic effects from necrotic effects, Annexin V and PI staining were performed (Figure 3A). It was found that $\mathrm{Ni}(\mathrm{II})$ thiosemicarbazone compound had apoptotic effect on HL60 cells. Amount of Annexin V and PI double positive HL60 cells was $31.1 \%$ after 24 hours incubation with this compound in $124 \mu \mathrm{mol} / \mathrm{l}$. On the other hand, only Annexin V positive HL60 cells constituted $12 \%$ of all cells. Our results showed total amount of apoptotic cells was $43.1 \%$ after 24 hours comparing with controls.

To confirm the apoptotic effects of this compound, we also used DNA fragmentation analysis. DNA fragmentation is one of the characteristics of apoptosis (McCarthy
A

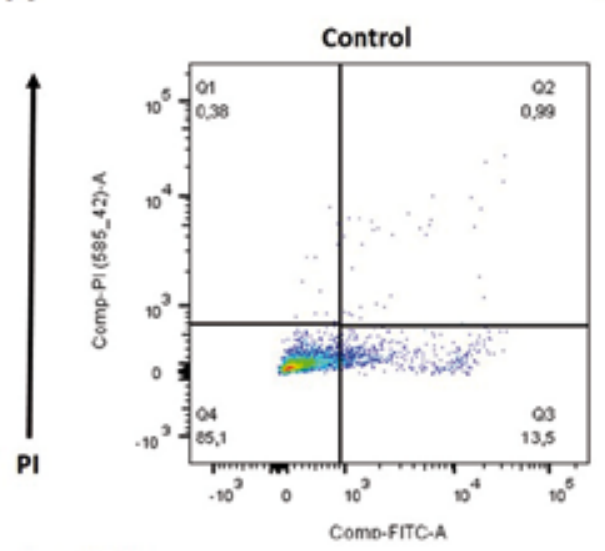

HL60

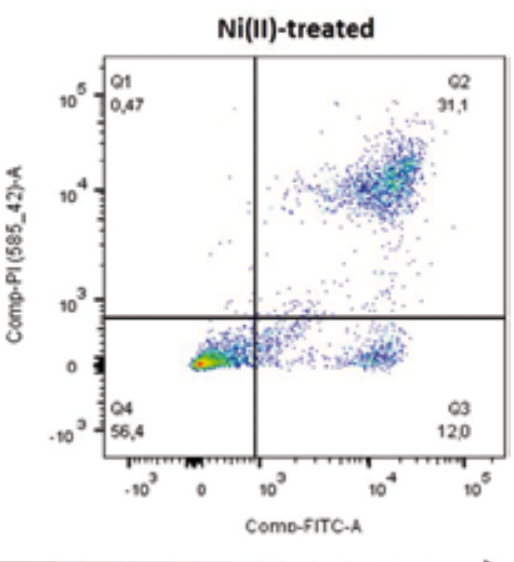

B

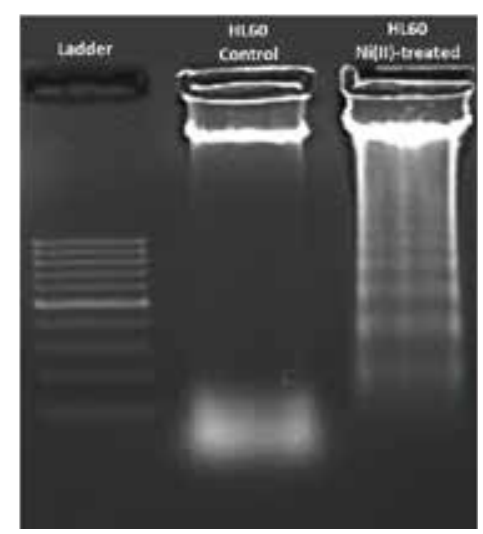

Figure 3. A. Flow cytometry analysis of apoptotic effects of Ni(II) thiosemicarbazone compound on HL60 cells. B. Screening apoptotic effects of $\mathrm{Ni}(\mathrm{II})$ thiosemicarbazone compound on HL60 with DNA fragmentation method. 


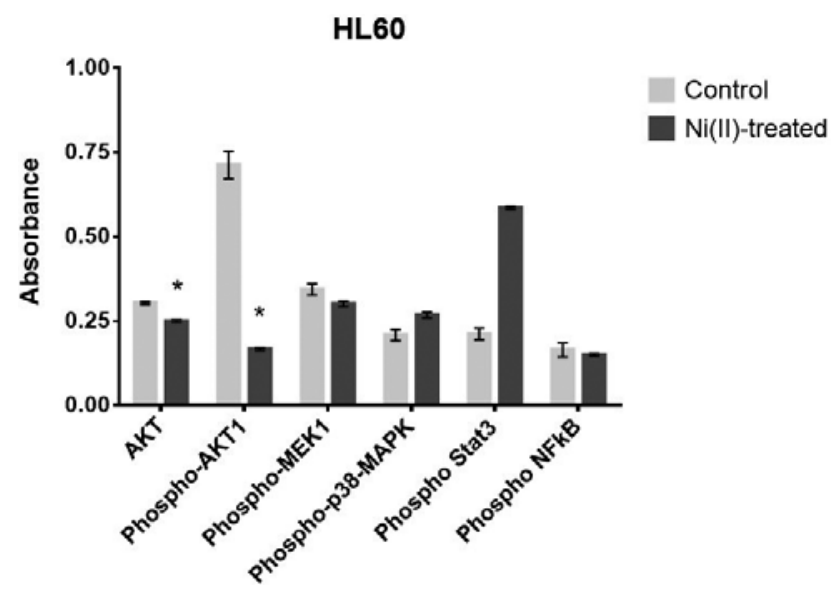

Figure 4. Effects of $\mathrm{Ni}(\mathrm{II})$ thiosemicarbazone compound on the levels of Phospho-Akt1, Phospho-MEK1, Phospho-p38-MAPK,PhosphoStat3, Phospho-NFKB protein in HL60 cells. Optical density of each well was measured at $450 \mathrm{~nm}$ test wavelength. ${ }^{\star} p<0.05$.

and Evan 1998). Fragmented genomic DNA of HL60 cells that was treated with $\mathrm{Ni}$ (II) thiosemicarbazone compound was screened via DNA fragmentation assay (Figure 3B). Our flow cytometry analysis and DNA fragmentation assay results showed that the $\mathrm{Ni}(\mathrm{II})$ thiosemicarbazone compound induces apoptosis in HL60 cells (Figure 3). Because of this apoptotic properties, $\mathrm{Ni}$ (II) thiosemicarbazone compound may have anticancer drug potential for HL60 human promyelocytic leukemia cells.

In order to search the possible roles of $\mathrm{Ni}$ (II) thiosemicarbazone compound on the changes of the levels of intracellular signal nodes of HL60 cells, we measured levels of Phospho NFкB (Ser536), Phospho Stat3 (Tyr705), Phospho-p38 MAPK (Thr180/Tyr182), Phospho-MEK1 (Ser217/221) and Phospho-Akt1(Ser473) quantities in the cells treated with this $\mathrm{Ni}$ (II) thiosemicarbazone compound. We used Signaling Nodes Sandwich ELISA kits to determine the effects of the $\mathrm{Ni}$ (II) thiosemicarbazone compound on HL60 cells on intracellular signaling nodes. The results and their significances were shown in Figure 4. According to our results, Ni(II) thiosemicarbazone compound significantly decreased the level of Phospho-Akt1 protein. However, other protein levels did not change significantly after 24 hour incubation of HL60 cells with the $\mathrm{Ni}$ (II) thiosemicarbazone compound (Figure 4).

To understand apoptotic mechanisms of the Ni(II) thiosemicarbazone compound on HL60 cells, we investigated effects of $\mathrm{Ni}$ (II) thiosemicarbazone compound on the apoptotic signaling pathway by using Apoptosis Multi-Target Sandwich ELISA kit. HL60 cells were incubated with Ni(II) thiosemicarbazone compound and the changes levels of Phospho-p53(Ser15), p53, Cleaved caspase 3 (Asp175), Cleaved PARP(Asp214), Phospho-BAD(Ser112) and BAD proteins were determined. The results were shown in Figure 5. While the $\mathrm{Ni}$ (II) thiosemicarbazone compound decreased levels of cleaved PARP, phospho-Bad, Bad proteins, it significantly increased the levels of the p53 and cleaved caspase- 3 proteins in HL60 cells.

\section{Discussion}

HL60 and ECV304 cells were treated with $\mathrm{Ni}(\mathrm{II})$ thiosemicarbazone compound at different concentration $(124,25,12,2.5$, $0.25 \mu \mathrm{mol} / \mathrm{l}$ ) and cell viability was measured via MTT (assay. $\mathrm{Ni}$ (II) compound showed cytotoxic activity above $55 \%$ against HL60 human promyelocytic leukemia cells in $124 \mu \mathrm{mol} / \mathrm{l}$ (Figure 2). Furthermore, it showed about $40 \%$ cytotoxicity on HL60 cells in $25 \mu \mathrm{mol} / 1$. According to the cytotoxicity results, $\mathrm{IC}_{50}$ values of HL60 and ECV304 cells are $58.8 \mu \mathrm{mol} / \mathrm{l}$ and $>124 \mu \mathrm{mol} / \mathrm{l}$, respectively. $\mathrm{Ni}(\mathrm{II})$ thiosemicarbazone compound, of which $\mathrm{IC}_{50}$ value is not cytotoxic for ECV304 cells, have therapeutic potential as antitumor agents.

Apoptotic effect of the $\mathrm{Ni}$ (II) thiosemicarbazone compound on HL60 cells was analysed by using flow cytometry analysis. Results demonstrated that $\mathrm{Ni}$ (II) thiosemicarbazone compound had apoptotic effect on HL60 cells. Amount of both Annexin V and PI double positive HL60 cells was 31.1\% after 24 hours incubation with this compound at $124 \mu \mathrm{mol} / \mathrm{l}$ concentration. Whereas, only Annexin V positive HL60 cells constituted $12 \%$ of all cells. Our results showed that total amount of apoptotic cells was $43.1 \%$ after 24 hours comparing with controls. Also DNA fragmentation assays demonstrated that the $\mathrm{Ni}$ (II) thiosemicarbazone compound induces apoptosis in HL60 cells (Figure 3). Their apoptotic properties imply that

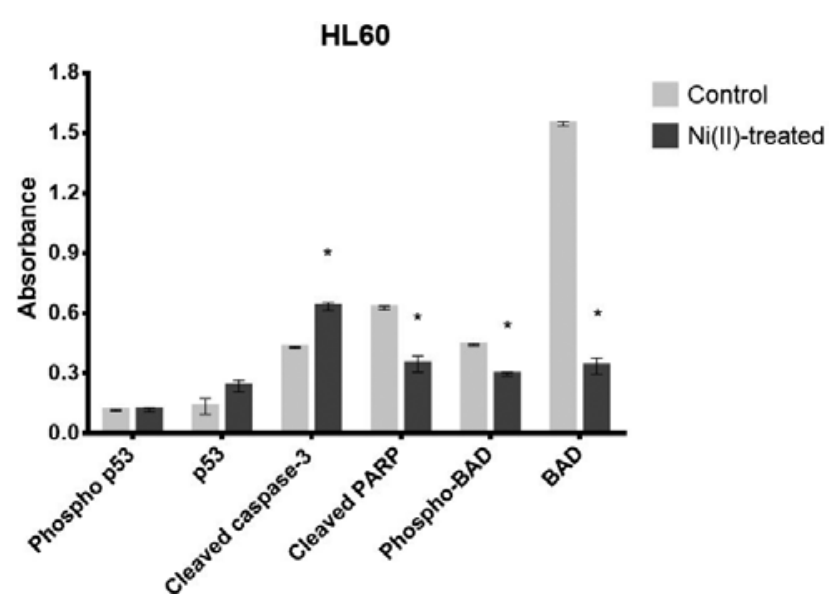

Figure 5. Effects of $\mathrm{Ni}(\mathrm{II})$ thiosemicarbazone compound on the levels of Phospho-p53,p53, Cleaved caspase 3, Cleaved PARP, Phospho-BAD and BAD protein in HL60 cells. Optical density of each well was measured at $450 \mathrm{~nm}$ test wavelength. ${ }^{\star} p<0.05$. 
$\mathrm{Ni}(\mathrm{II})$ thiosemicarbazone compound may have anticancer drug potential for HL60 human promyelocytic leukemia cells.

In order to search whether a possible role of $\mathrm{Ni}$ (II) thiosemicarbazone compound on the changes of the levels of intracellular signal nodes of HL60 cells, we measured levels of Phospho NFkB (Ser536), Phospho Stat3 (Tyr705), Phospho-p38 MAPK (Thr180/Tyr182), Phospho-MEK1 (Ser217/221) and Phospho-Akt1(Ser473) quantities in the cells treated with this $\mathrm{Ni}$ (II) compound. According to our results, $\mathrm{Ni}$ (II) compound significantly decreased the level of Phospho-Akt1 protein (Figure 4).

Akt protein plays role in cell survival and apoptosis (Zhou et al. 2000). Activation of Akt has a fundamental role in cell survival signalling (Franke et al. 2003). Therefore, decreasing of Akt activation induces apoptosis by preventing cancer cell growth. Moreover, previous studies have showed that Akt inhibitors induce apoptosis in chronic lymphocytic leukemia cells (de Frias et al. 2009). In this study we showed Phospho-Akt1 protein level decreased with the $\mathrm{Ni}$ (II) thiosemicarbazone compound treatment on leukemic HL60 cell line compared with untreated HL60 cells. According to our data, the $\mathrm{Ni}$ (II) thiosemicarbazone compound decreased Akt1 level and induces apoptosis in HL60 cells.

To determine apoptotic mechanisms of the $\mathrm{Ni}(\mathrm{II})$ thiosemicarbazone compound, and the changes in levels of Phospho-p53(Ser15), p53, Cleaved caspase 3 (Asp175), Cleaved PARP(Asp214), Phospho-BAD(Ser112) and BAD proteins, HL60 cells were treated with $\mathrm{Ni}(\mathrm{II})$ thiosemicarbazone compound. While the Ni(II) thiosemicarbazone compound decreased levels of cleaved PARP, phospho-Bad, Bad proteins, it significantly increased the levels of the p53 and cleaved caspase- 3 proteins in HL60 cells.

Protein p53 plays a crucial role in DNA repair, genomic stability, senescence, cell cycle control, and apoptosis (Harris 1996; Levine 1997; Baell and Huang 2002; Cory et al. 2003). Our results propose that increased level of p53 protein can stimulate apoptosis by inhibiting $\mathrm{Bcl}-2$ anti-apoptotic protein and accelerate death process of cancer cells.

Moreover, caspases are important mediators of apoptosis. Especially, caspase- 3 that is responsible for the proteolytic cleavage of many key proteins is a critical executioner of apoptosis (Porter and Jänicke 1999; Mcllwain et al. 2013). According to our result, increasing levels of cleaved caspase-3 protein with the $\mathrm{Ni}$ (II) thiosemicarbazone compound incubation can induce apoptosis in HL60 cells.

PARP protein plays role in repair of DNA damage and cell survival and is also a coactivator of NF- $\mathrm{kB}$ and NF-kB proteins linked each other in cell survival mechanism (Veuger et al. 2009; Nowsheen et al. 2012). We found that the Ni(II) thiosemicarbazone compound decreased levels of cleaved PARP protein and this result suggests that inhibition of PARP protein can inhibit cell survival and induce apoptosis.
Emirdağ-Öztürk et al. showed that Co(II) complexes of gypsogenin thiosemicarbazone glyoxime has apoptotic effect on HL60 cells. However, intracellular signalling pathways of this molecule in HL60 cells and its effects on non-cancerous cells are not known (Emirdag-Ozturk et al. 2014). Bioinformatic meta-analysis of interactions all new synthesized thiosemicarbazones in literature with intracellular signalling nodes in cancer cells can be helpful to understand importance of metal ions and structural properties of thiosemicarbazones against various cancer cells and non-cancerous cells.

In this study, we detected decreased Akt1 and phospho$\mathrm{BAD}$ levels. BAD protein is a pro-apoptotic member of $\mathrm{Bcl}-2$ gene family and pro-apoptotic activity of BAD can be inhibited by phosphorylation (Hsu et al. 1997). Several previous studies has suggested that BAD mediate the anti-apoptotic effects of PI3K/Akt pathway (Datta et al. 1997; del Peso et al. 1997). Akt protein phosphorylates BAD protein and blocks the dimerization of BAD with Bcl-2 or Bcl-xl (del Peso et al. 1997). Inhibitory effect of $\mathrm{Ni}$ (II) thiosemicarbazone compound on Akt prevents inhibition of BAD by decreasing phospho$\mathrm{BAD}$ protein level. Moreover, the inhibition effect of Akt on phosphorylation of Bad might decrease level of antiapoptoic $\mathrm{Bcl}-2$ and Bcl-xl protein and induce apoptosis (Fu et al. 2014).

Based on our result we suggest that decreasing level of phospho-BAD protein with the $\mathrm{Ni}$ (II) thiosemicarbazone compound can trigger apoptosis on HL60 leukemia cells. We analyzed and compared our results with the literature and predicted the possible apoptotic signaling pathways of the $\mathrm{Ni}$ (II) thiosemicarbazone compound on HL60 cells. Our results suggested that the Nickel(II) thiosemicarbazone compound, as a potential anticancer drug, could induce apoptosis through the inhibition of PI3K/Akt pathway or p53 pathway in HL60 cells. On the other hand, inhibition of PARP or BAD and increase caspase-3 levels are other possible apoptotic pathways for this new compound. Understanding of its apoptotic mechanism can be helpful to identity therapeutic index of this compound targeting various cancer cells. All these results imply that its structural properties are very important for selective cytotoxicity and apoptotic effect against HL60 cells.

Conflict of interest: The authors have no conflict of interest.

\section{References}

Afrasiabi Z., Sinn E., Chen J., Ma Y., Rheingold A. L., Zakharov L. N., Rath N., Padhye S. (2004): Appended 1, 2-naphthoquinones as anticancer agents 1: synthesis, structural, spectral and antitumor activities of ortho-naphthaquinone thiosemicarbazone and its transition metal complexes. Inorg. Chim. Acta 357, 271-278

http://dx.doi.org/10.1016/S0020-1693(03)00484-5 
Atasever-Arslan B., Yilancioglu K., Bekaroglu M. G., Taskin E., Altinoz E., Cetiner S. (2015): Cytotoxic effect of extract from Dunaliella salina against SH-SY5Y neuroblastoma cells. Gen. Physiol. Biophys. 34, 201-207 http://dx.doi.org/10.4149/gpb_2014034

Atasever-Arslan B., Yilancioglu K., Timucin A. C., Kalkan Z., Gur H., Deniz E., Erman B., Cetiner S. (2016): Screening of new antileukemic agents from essential oils of algae extracts and computational modeling of their interactions with intracellular signaling nodes. Eur. J. Pharm. Sci. 83, 120-131 http://dx.doi.org/10.1016/j.ejps.2015.12.001

Atasever B., Ülküseven B., Bal-Demirci T., Erdem-Kuruca S., Solakoğlu Z. (2010): Cytotoxic activities of new iron(III) and nickel(II) chelates of some S-methyl-thiosemicarbazones on K562 and ECV304 cells. Invest. New Drugs 28, 421-432 http://dx.doi.org/10.1007/s10637-009-9272-2

Baell J. B., Huang D. C. S. (2002): Prospects for targeting the Bcl-2 family of proteins to develop novel cytotoxic drugs. Biochem. Pharmacol. 64, 851-863 http://dx.doi.org/10.1016/S0006-2952(02)01148-6

Bal Demirci T., Atasever B., Solakoğlu Z., Erdem-Kuruca S., Ülküseven B. (2007): Synthesis, characterisation and cytotoxic properties of the N1,N4-diarylidene-S-methyl-thiosemicarbazone chelates with $\mathrm{Fe}(\mathrm{III})$ and $\mathrm{Ni}(\mathrm{II})$. Eur. J. Med. Chem. 42, 161-167 http://dx.doi.org/10.1016/j.ejmech.2006.09.004

Beraldo H., Gambino D. (2004): The wide pharmacological versatility of semicarbazones, thiosemicarba-zones and their metal complexes. Mini Rev. Med. Chem. 4, 31-40 http://dx.doi.org/10.2174/1389557043487484

Casas J. S., Garcia-Tasende M. S., Sordo J. (2000): Main group metal complexes of semicarbazones and thiosemicarbazones. A structural review. Coord. Chem. Rev. 209, 197-261 http://dx.doi.org/10.1016/S0010-8545(00)00363-5

Cory S., Huang D. C. S., Adams J. M. (2003): The Bcl-2 family: roles in cell survival and oncogenesis. Oncogene 22, 8590-8607 http://dx.doi.org/10.1038/sj.onc.1207102

Datta S. R., Dudek H., Tao X., Masters S., Fu H., Gotoh Y., Greenberg M. E. (1997): Akt phosphorylation of BAD couples survival signals to the cell-intrinsic death machinery. Cell 91, 231-241 http://dx.doi.org/10.1016/S0092-8674(00)80405-5

de Frias M., Iglesias-Serret D., Cosialls A. M., Coll-Mulet L., Santidrián A. F., González-Gironès D. M., de la Banda E., Pons G., Gil J. (2009): Akt inhibitors induce apoptosis in chronic lymphocytic leukemia cells. Haematologica 94, 1698-1707 http://dx.doi.org/10.3324/haematol.2008.004028

De Logu A., Saddi M., Onnis V., Sanna C., Congiu C., Borgna R., Cocco M. T. (2005): In vitro antimycobacterial activity of newly synthesised S-alkylisothiosemicarbazone derivatives and synergistic interactions in combination with rifamycins against Mycobacterium avium. Int. J. Antimicrob. Agents 26, 28-32 http://dx.doi.org/10.1016/j.ijantimicag.2005.03.005

del Peso L., González-García M., Page C., Herrera R., Nu-ez G. (1997): Interleukin-3-induced phosphorylation of BAD through the protein kinase Akt. Science 278, 687-689 http://dx.doi.org/10.1126/science.278.5338.687

Emirdağ-Öztürk S., Babahan İ., Özmen A. (2014): Synthesis, characterization and in vitro anti-neoplastic activity of gypsogenin derivatives. Bioorg. Chem. 53, 15-23 http://dx.doi.org/10.1016/j.bioorg.2013.12.001

Franke T. F., Hornik C. P., Segev L., Shostak G. A., Sugimoto C. (2003): PI3K/Akt and apoptosis: size matters. Oncogene 22, 8983-8998

http://dx.doi.org/10.1038/sj.onc.1207115

Fu Z., Ren L., Wei H., Lv J., Che X., Zhu Z., Jia J., Wang L., Lin G., Lu R., Yao Z. (2014): Effects of Tyroserleutide on phosphatidylinositol 3'-kinase/AKT pathway in human hepatocellular carcinoma cell. J. Drug Target 22, 146-155

http://dx.doi.org/10.3109/1061186X.2013.844820

Genova P., Varadinova T., Matesanz A. I., Marinova D., Souza P. (2004): Toxic effects of bis(thiosemicarbazone) compounds and its palladium(II) complexes on herpes simplex virus growth. Toxicol. Appl. Pharmacol. 197, 107-112 http://dx.doi.org/10.1016/j.taap.2004.02.006

Harris C. C. (1996): Structure and function of the p53 tumor suppressor gene: clues for rational cancer therapeutic strategies. J. Natl. Cancer Inst. 88, 1442-1455 http://dx.doi.org/10.1093/jnci/88.20.1442

Hsu S. Y., Kaipia A., Zhu L., Hsueh A. J. (1997): Interference of BAD (Bcl-xL/Bcl-2-associated death promoter)-induced apoptosis in mammalian cells by 14-3-3 isoforms and P11. Mol. Endocrinol. 11, 1858-1867

Kesel A. J. (2011): Broad-spectrum antiviral activity including human immunodeficiency and hepatitis $\mathrm{C}$ viruses mediated by a novel retinoid thiosemicarbazone derivative. Eur. J. Med. Chem. 46, 1656-1664 http://dx.doi.org/10.1016/j.ejmech.2011.02.014

Levine A. J. (1997): p53, the cellular gatekeeper for growth and division. Cell 88, 323-331 http://dx.doi.org/10.1016/S0092-8674(00)81871-1

Matesanz A. I., Souza P. (2007): Palladium and platinum 3,5diacetyl-1,2,4-triazol bis(thiosemicarbazones): chemistry, cytotoxic activity and structure-activity relationships. J. Inorg. Biochem. 101, 245-253 http://dx.doi.org/10.1016/j.jinorgbio.2006.09.024

McCarthy N. J., Evan G. I. (1998): Methods for detecting and quantifying apoptosis. Curr. Top. Dev. Biol. 36, 259-278 http://dx.doi.org/10.1016/S0070-2153(08)60507-4

Mcllwain D. R., Berger T., Mak T. W. (2013): Caspase functions in cell death and disease. Cold Spring Harb. Perspect. Biol. 5, a008656

Mendes I. C., Costa F. B., de Lima G. M., Ardisson J. D., GarciaSantos I., Castineiras A., Beraldo H. (2009): Tin(IV) complexes with 2-pyridineformamide-derived thiosemicarbazones: Antimicrobial and potential antineoplasic activities. Polyhedron. 28, 1179-1185 http://dx.doi.org/10.1016/j.poly.2009.01.028

Noblia P., Vieites M., Parajón-Costa B. S., Baran E. J., Cerecetto H., Draper P., González M., Piro O. E., Castellano E. E., Azqueta A., López de Ceráin A., Monge-Vega A., Gambino D. (2005): Vanadium $(\mathrm{V})$ complexes with salicylaldehyde semicarbazone derivatives bearing in vitro anti-tumor activity toward kidney tumor cells (TK-10): crystal structure of [VVO2(5-bromosalicylaldehyde semicarbazone)]. J. Inorg. Biochem. 99, 443-451 http://dx.doi.org/10.1016/j.jinorgbio.2004.10.019

Nowsheen S., Cooper T., Bonner J. A., LoBuglio A. F., Yang E. S. (2012): HER2 overexpression renders human breast cancers sensitive 
to PARP inhibition independently of any defect in homologous recombination DNA repair. Cancer Res. 72, 4796-4806 http://dx.doi.org/10.1158/0008-5472.CAN-12-1287

Oliveira C. G., Ivo da S., Maia P., Souza P. C., Pavan F. R., Leitec C. Q. F., Viana R. B., Batista A. A., Nascimento O. R., Deflon V. M. (2014): Manganese(II) complexes with thiosemicarbazones as potential anti-Mycobacterium tuberculosis agents. J. Inorg. Biochem. 132, 21-29 http://dx.doi.org/10.1016/j.jinorgbio.2013.10.011

Otero L., Vieites M., Boiani L., Denicola A., Rigol C., Opazo L., OleaAzar C., Maya J. D., Morello A., Krauth-Siegel R. L., Piro O. E., Castellano E., González M., Gambino D., Cerecetto H. (2006): Novel antitrypanosomal agents based on palladium nitrofurylthiosemicarbazone complexes: DNA and redox metabolism as potential therapeutic targets. J. Med. Chem. 49, 3322-3331 http://dx.doi.org/10.1021/jm0512241

Pırıldar S., Sütlüpınar N., Atasever B., Erdem-Kuruca S., Papouskova B., Šimánek V. (2010): Chemical constituents of the different parts of Colchicum baytopiorum and their cytotoxic activities on K562 and HL60 cell lines. Pharm. Biol. 48, 32-39 http://dx.doi.org/10.3109/13880200903029373

Porter A. G., Jänicke R. U. (1999): Emerging roles of caspase-3 in apoptosis. Cell Death Differ. 6, 99-104 http://dx.doi.org/10.1038/sj.cdd.4400476

Raja D. S., Bhuvanesh N. S. P., Natarajan K. (2011): Biological evaluation of a novel water soluble sulphur bridged binuclear copper(II) thiosemicarbazone complex. Eur. J. Med. Chem. 46, 4584-4594 http://dx.doi.org/10.1016/j.ejmech.2011.07.038

Rodriguez-Arguelles M. C., Lopez-Silva E. C., Sanmartin J., Pelagatti P., Zani F. (2005): Copper complexes of imidazole-2-, pyrrole-2- and indol-3-carbaldehyde thiosemicarbazones: inhibitory activity against fungi and bacteria. J. Inorg. Biochem. 99, 2231-2239 http://dx.doi.org/10.1016/j.jinorgbio.2005.07.018

Suda K., Rothen-Rutishauser B., Günthert M., Wunderli-Allenspach H. (2001): Phenotypic characterization of human umbilical vein endothelial (ECV304) and urinary carcinoma (T24) cells: endothelial versus epithelial features. In Vitro Cell Dev. Biol. Anim. 37, 505-514

http://dx.doi.org/10.1290/1071-2690(2001)037<0505:PCOHUV>2.0.CO;2

Svobodova H., Jost P., Stetina R. (2012): Cytotoxicity and genotoxicity evaluation of antidote oxime HI-6 tested on eight cell lines of human and rodent origin. Gen. Physiol. Biophys. 31, 77-84 http://dx.doi.org/10.4149/gpb_2012_010

Takaki K., Higuchi Y., Hashii M., Ogino C., Shimizu N. (2014): Induction of apoptosis associated with chromosomal DNA fragmentation and caspase- 3 activation in leukemia L1210 cells by $\mathrm{TiO} 2$ nanoparticles. J. Biosci. Bioeng. 117, 129-133 http://dx.doi.org/10.1016/j.jbiosc.2013.06.003

Tarasconi P., Capacchi S., Pelosi G., Cornia M., Albertini R., Bonati A., Dall'Aglio P. P., Lunghi P., Pinelli S. (2000): Synthesis, spectroscopic characterization and biological properties of new natural aldehydes thiosemicarbazones. Bioorg. Med. Chem. 8, $157-162$ http://dx.doi.org/10.1016/S0968-0896(99)00260-6

Varadinova T., Kovala-Demertzi D., Rupelieva M., Demertzis M., Genova P. (2001): Antiviral activity of platinum (II) and palladium (II) complexes of pyridine-2-carbaldehyde thiosemicarbazone. Acta Virol. 45, 87-94

Veuger S. J., Hunter J. E., Durkacz B. W. (2009): Ionizing radiationinduced NF-kappaB activation requires PARP-1 function to confer radioresistance. Oncogene 28, 832-842 http://dx.doi.org/10.1038/onc.2008.439

Vieites M., Otero L., Santos D., Olea-Azar C., Norambuena E., Aguirre G., Cerecetto H., González M., Kemmerling U., Morello A., Diego Maya J., Gambino D. (2009): Platinum-based complexes of bioactive 3-(5-nitrofuryl)acroleine thiosemicarbazones showing anti-Trypanosoma cruzi activity. J. Inorg. Biochem. 103, 411-418 http://dx.doi.org/10.1016/j.jinorgbio.2008.12.004

Vrdoljak V., DilovićI I., Rubcić M., Kraljević Pavelić S., Kralj M., Matković-Calogović D., Piantanida I., Novak P., Rozman A., Cindrić M.(2010): Synthesis and characterisation of thiosemicarbazonato molybdenum(VI) complexes and their in vitro antitumor activity. Eur. J. Med. Chem. 45, 38-48 http://dx.doi.org/10.1016/j.ejmech.2009.09.021

Yamazaki C. (1975): The structure of isothiosemicarbazones. Can. J. Chem. 53, 610-615 http://dx.doi.org/10.1139/v75-085

Yanardag R., Bal Demirci T., Ülküseven B., Bolkent S., Tunali S., Bolkent S. (2009): Synthesis, characterization and antidiabetic properties of N(1)-2,4-dihydroxybenzylidene-N(4)-2-hydroxybenzylidene-S-methyl-thiosemicarbazidato-oxovanadium(IV). Eur. J. Med. Chem. 44, 818-826 http://dx.doi.org/10.1016/j.ejmech.2008.04.023

Zhou H., Li X. M., Meinkoth J., Pittman R. N. (2000): Akt regulates cell survival and apoptosis at a postmitochondrial level. J. Cell Biol. 151, 483-494 http://dx.doi.org/10.1083/jcb.151.3.483

Received: December 16, 2015

Final version accepted: April 5, 2016 